\title{
Modelling and optimisation of Indian traditional agriculture supply chain to reduce
} post-harvest loss and $\mathrm{CO}_{2}$ emission

\author{
Manivannan Chandrasekaran and Rajesh Ranganathan \\ Department of Mechanical Engineering, Coimbatore Institute of Technology, \\ Coimbatore, India
}

Indian

traditional

agriculture

supply chain \\ 1817}

Received 20 September 2016

Revised 28 February 2017

30 May 2017

Accepted 14 June 2017

\begin{abstract}
Purpose - The purpose of this paper is to reduce the post-harvest loss occurring through respiration and $\mathrm{CO}_{2}$ emission produce by the selected produces, during logistics. This paper proposes a supply chain (SC) structure for the Indian traditional agriculture SC planning model to reduce post-harvest loss and mixed closed transportation to reduce $\mathrm{CO}_{2}$ emission.

Design/methodology/approach - The Indian agriculture SC structure is modeled and solved by genetic algorithm using a MATLAB Optimization toolbox. The respiration rate is measured by a static method. These values are applied in an SC planning model and the post-harvest loss and its corresponding $\mathrm{CO}_{2}$ emission are estimated.

Findings - This paper proposes a supply structure for the Indian traditional agriculture SC to reduce the post-harvest loss; the experiments measured the respiration rate to estimate the $\mathrm{CO}_{2}$ emission. The mixed closed transportation method is found to be suitable for short-purpose domestic transportation.

Research limitations/implications - The optimized supply structure leads to unemployment through eliminating the intermediaries. Therefore, further research encourages the conversion of intermediaries into hub instead of eliminating them.

Practical implications - This paper includes implications for the development of Indian traditional agriculture SC by an optimized supply structure and novel transportation method for the selected agriculture produces based on compatibility.

Originality/value - This paper identified that the agriculture produces respiration can also emit the $\mathrm{CO}_{2}$. The closed transportation method can reduce the $\mathrm{CO}_{2}$ emission of produces respiration than traditional open transportation.
\end{abstract}

Keywords Transportation, Carbon dioxide emission, Post-harvest losses, Respiration,

Supply chain planning

Paper type Research paper

\section{Nomenclature}

$\begin{array}{llll}\text { Sets } & & D & \text { Demand or production } \\ n & \text { Produces } & Q & \text { Supply quantity } \\ f & \text { Farmers } & T & \text { Transport quantity } \\ g & \text { Agents } & W & \text { Loss quantity } \\ a & \text { Auctioneers } & \mathrm{PQ} & \text { Supply percentage } \\ l & \text { Whole sellers } & \mathrm{PW} & \text { Loss percentage } \\ r & \text { Retail store } & C & \text { Carbon dioxide emission } \\ e & \text { Customer } & & \end{array}$

(C) Manivannan Chandrasekaran and Rajesh Ranganathan. Published by Emerald Publishing Limited. This article is published under the Creative Commons Attribution (CC BY 4.0) licence. Anyone may reproduce, distribute, translate and create derivative works of this article (for both commercial \& non-commercial purposes), subject to full attribution to the original publication and authors. The full terms of this licence may be seen at: http://creativecommons.org/licences/by/4.0/legalcode

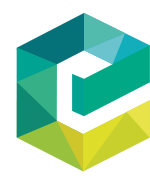

Industrial Management \& Data Systems Vol. 117 No. 9, 2017 pp. 1817-1841 Emerald Publishing Limited 0263-5577 DOI 10.1108/IMDS-09-2016-0383 
IMDS 117,9

1818

\section{Decision variables}

$D_{n} \quad$ Demand or production of $n$ produces

$\mathrm{PQ}_{\mathrm{nfg}} \quad$ Supply percentage of produce $n$ from farmer to agent

$\mathrm{PQ}_{\mathrm{nfa}} \quad$ Supply percentage of produce $n$ from farmer to auctioneer Supply percentage of produce $n$ from farmer to whole seller

$\mathrm{PQ}_{\mathrm{nfr}} \quad$ Supply percentage of produce $n$ from farmer to retail store

$\mathrm{PQ}_{\mathrm{nfe}} \quad$ Supply percentage of produce $n$ from farmer to customer

$P Q_{\text {nga }}$

$\mathrm{PQ}_{\mathrm{ngl}}$

$\mathrm{PQ}_{\text {ngr }}$

$P Q_{\text {nge }}$

$\mathrm{PQ}_{\text {nal }}$

$P Q_{\text {nar }}$

$\mathrm{PQ}_{\text {nae }}$

$\mathrm{PQ}_{\mathrm{nlr}}$

$\mathrm{PQ}_{\text {nle }}$

$\mathrm{PQ}_{\text {nre }}$

$\mathrm{PW}_{\mathrm{nf}}$

$\mathrm{PW}_{\text {ng }}$

$\mathrm{PW}_{\text {na }}$

$\mathrm{PW}_{\mathrm{nl}}$

$\mathrm{PW}_{\mathrm{nr}}$

$\mathrm{PW}_{\text {nfg }}$

$\mathrm{PW}_{\text {nfa }}$

$\mathrm{PW}_{\mathrm{nfl}}$

$\mathrm{PW}_{\text {nfr }}$
Supply percentage of produce $n$ from agent to auctioneer Supply percentage of produce $n$ from agent to whole seller Supply percentage of produce $n$ from agent to retail store

\section{Supply percentage of produce $n$} from agent to customer

Supply percentage of produce $n$ from auctioneer to whole seller

Supply percentage of produce $n$ from auctioneer to retail store

Supply percentage of produce $n$ from auctioneer to customer Supply percentage of produce $n$ from whole seller to retail store Supply percentage of produce $n$ from whole seller to customer Supply percentage of produce $n$ from retail to customer Loss percentage of produce $n$ at famer Loss percentage of produce $n$ at agent Loss percentage of produce $n$ at auctioneer

\section{Loss percentage of produce $n$ at $\quad Q_{\mathrm{nfl}}$} whole seller

\section{Loss percentage of produce $n$ at $\quad Q_{\mathrm{nf}}$} retail store

\section{Loss percentage of produce $n$ during} transport from farmer to agent

Loss percentage of produce $n$ during transport from farmer to auctioneer Loss percentage of produce $n$ during transport from farmer to whole seller Loss percentage of produce $n$ during transport from farmer to retail store

$Q_{\mathrm{nl}}$

$Q_{\mathrm{nr}}$
$\mathrm{PW}_{\text {nfe }} \quad$ Loss percentage of produce $n$ during transport from farmer to customer

$\mathrm{PW}_{\text {nga }} \quad$ Loss percentage of produce $n$ during transport from agent to auctioneer

$\mathrm{PW}_{\text {ngl }} \quad$ Loss percentage of produce $n$ during transport from agent to whole seller

$\mathrm{PW}_{\text {ngr }} \quad$ Loss percentage of produce $n$ during transport from agent to retail store

$\mathrm{PW}_{\text {nge }} \quad$ Loss percentage of produce $n$ during transport from agent to customer

$\mathrm{PW}_{\text {nal }} \quad$ Loss percentage of produce $n$ during transport from auctioneer to whole seller

$\mathrm{PW}_{\text {nar }} \quad$ Loss percentage of produce $n$ during transport from auctioneer to retail store

$\mathrm{PW}_{\text {nae }} \quad$ Loss percentage of produce $n$ during transport from auctioneer to customer

$\mathrm{PW}_{\mathrm{nlr}} \quad$ Loss percentage of produce $n$ during transport from whole seller to retail store

$\mathrm{PW}_{\text {nle }} \quad$ Loss percentage of produce $n$ during transport from whole seller to customer

$C_{n} \quad$ Carbon dioxide emission rate of produce $n$

\section{Other parameters}

$Q_{\mathrm{nf}} \quad$ Capacity of farmer

$Q_{\mathrm{ng}} \quad$ Capacity of agent

$Q_{\text {na }} \quad$ Capacity of auctioneer

$Q_{\text {nfg }}$

Capacity of whole seller

Capacity of retail

Supply quantity of produce $n$ from farmer to agent

Supply quantity of produce $n$ from farmer to auctioneer

Supply quantity of produce $n$ from farmer to whole seller

Supply quantity of produce $n$ from farmer to retail store

Supply quantity of produce $n$ from farmer to customer

Supply quantity of produce $n$ from agent to auctioneer

Supply quantity of produce $n$ from agent to whole seller

Supply quantity of produce $n$ from agent to retail store 
$Q_{\text {nge }} \quad$ Supply quantity of produce $n$ from $W_{\mathrm{nl}}$ agent to customer

$Q_{\text {nal }} \quad$ Supply quantity of produce $n$ from $W_{\mathrm{nr}}$ auctioneer to whole seller

$Q_{\text {nar }} \quad$ Supply quantity of produce $n$ from $W_{\text {nfg }}$ auctioneer to retail store

$Q_{\text {nae }} \quad$ Supply quantity of produce $n$ from $W_{\text {nfa }}$ auctioneer to customer

$Q_{\mathrm{nlr}} \quad$ Supply quantity of produce $n$ from $W_{\mathrm{nfl}}$ whole seller to retail store

$Q_{\text {nle }} \quad$ Supply quantity of produce $n$ from $W_{\text {nfr }}$ whole seller to customer

$Q_{\text {nre }} \quad$ Supply quantity of produce $n$ from $\quad W_{\text {nfe }}$ retail to customer

$Q_{\text {ne }} \quad$ Customer

Transport quantity of produce $n$

$T_{\text {nfg }} \quad$ Transport quantity of produce $n \quad W_{\text {ngl }}$

from farmer to agent

$T_{\text {nfa }} \quad$ Transport quantity of produce $n \quad W_{\text {ngr }}$ from farmer to auctioneer

$T_{\text {nfl }} \quad$ Transport quantity of produce $n \quad W_{\text {nge }}$ from farmer to whole seller

$T_{\text {nfr }} \quad$ Transport quantity of produce $n \quad W_{\text {nal }}$ from farmer to retail store

$T_{\text {nfe }} \quad$ Transport quantity of produce $n \quad W_{\text {nar }}$ from farmer to customer

$T_{\text {nga }} \quad$ Transport quantity of produce $n \quad W_{\text {nae }}$ from agent to auctioneer

$T_{\text {ngl }} \quad$ Transport quantity of produce $n \quad W_{\mathrm{nlr}}$ from agent to whole seller

$T_{\text {ngr }} \quad$ Transport quantity of produce $n \quad W_{\text {nle }}$ from agent to retail store

$T_{\text {nge }} \quad$ Transport quantity of produce $n$ from agent to customer

$T_{\text {nal }} \quad$ Transport quantity of produce $n$ from auctioneer to whole seller

$T_{\text {nar }} \quad$ Transport quantity of produce $n$ from auctioneer to retail store

$T_{\text {nae }} \quad$ Transport quantity of produce $n$ from auctioneer to customer

$T_{\mathrm{nlr}} \quad$ Transport quantity of produce $n$ from whole seller to retail store

$T_{\text {nle }} \quad$ Transport quantity of produce $n$ from whole seller to customer

Wastage quantity of produce $n$

$W_{\mathrm{nf}} \quad$ Loss quantity of produce $n$ at famer $C_{\text {nfa }}$

$W_{\text {ng }} \quad$ Loss quantity of produce $n$ at agent

$W_{\text {na }} \quad$ Loss quantity of produce $n$ at auctioneer
Loss quantity of produce $n$ at

whole seller

Loss quantity of produce $n$ at retail store

Loss of produce $n$ during transport from farmer to agent

Loss of produce $n$ during transport from farmer to auctioneer

Loss of produce $n$ during transport from farmer to whole seller

Loss of produce $n$ during transport from farmer to retail store

Loss of produce $n$ during transport from farmer to customer

Loss of produce $n$ during transport from agent to auctioneer

Loss of produce $n$ during transport from agent to whole seller

Loss of produce $n$ during transport from agent to retail store

Loss of produce $n$ during transport from agent to customer

Loss of produce $n$ during transport from auctioneer to whole seller

Loss of produce $n$ during transport from auctioneer to retail store

Loss of produce $n$ during transport from auctioneer to customer

Loss of produce $n$ during transport from whole seller to retail store

Loss of produce $n$ during transport from whole seller to customer

Carbon Dioxide Emission $\mathrm{CO}_{2}$

$C_{\mathrm{nf}} \quad$ Carbon dioxide emission of produce $n$ at farmer

$C_{\text {ng }} \quad$ Carbon dioxide emission of produce $n$ at agent

$C_{\text {na }} \quad$ Carbon dioxide emission of produce $n$ at auctioneer

$C_{\mathrm{nl}} \quad$ Carbon dioxide emission of produce $n$ at whole seller

$C_{\mathrm{nr}} \quad$ Carbon dioxide emission of produce $n$ at retail

$C_{\text {nfg }} \quad$ Carbon dioxide emission of produce $n$ at agent

Carbon dioxide emission of produce $n$ from farmer to auctioneer Carbon dioxide emission of produce $n$ from farmer to whole seller

\section{Indian \\ traditional \\ agriculture \\ supply chain}

1819 


\begin{tabular}{|c|c|c|c|}
\hline & $C_{\mathrm{nfr}}$ & $\begin{array}{l}\text { Carbon dioxide emission of produce } \\
n \text { from farmer to retail store }\end{array}$ & $\mathrm{CW}_{\mathrm{nfg}}$ \\
\hline & $C_{\text {nfe }}$ & $\begin{array}{l}\text { Carbon dioxide emission of produce } \\
n \text { from farmer to customer }\end{array}$ & $\mathrm{CW}_{\mathrm{I}}$ \\
\hline & $C_{\text {nga }}$ & $\begin{array}{l}\text { Carbon dioxide emission of produce } \\
n \text { from agent to auctioneer }\end{array}$ & $\mathrm{C}$ \\
\hline \multirow[t]{15}{*}{1820} & $C_{\mathrm{ngl}}$ & Carbon dioxide emission of produce & \\
\hline & $C_{\text {ngr }}$ & $\begin{array}{l}n \text { from agent to whole seller } \\
\text { Carbon dioxide emission of produce } \\
n \text { from agent to retail store }\end{array}$ & $\mathrm{C}$ \\
\hline & $C_{\text {nge }}$ & $\begin{array}{l}\text { Carbon dioxide emission of produce } \\
n \text { from agent to customer }\end{array}$ & $\mathrm{CW}$ \\
\hline & $C_{\text {nal }}$ & $\begin{array}{l}\text { Carbon dioxide emission of produce } \\
n \text { from auctioneer to whole seller }\end{array}$ & \\
\hline & $C_{\text {nar }}$ & $\begin{array}{l}\text { Carbon dioxide emission of produce } \\
n \text { from auctioneer to retail store }\end{array}$ & \\
\hline & $C_{\text {nae }}$ & $\begin{array}{l}\text { Carbon dioxide emission of produce } \\
n \text { from auctioneer to customer }\end{array}$ & \\
\hline & $C_{\mathrm{nlr}}$ & $\begin{array}{l}\text { Carbon dioxide emission of produce } \\
n \text { from whole seller to retail store }\end{array}$ & \\
\hline & $C_{\text {nle }}$ & $\begin{array}{l}\text { Carbon dioxide emission of produce } \\
n \text { from whole seller to customer }\end{array}$ & $C_{1}$ \\
\hline & $C_{\text {nre }}$ & $\begin{array}{l}\text { Carbon dioxide emission of produce } \\
n \text { from retail to customer }\end{array}$ & $C_{\text {na }}$ \\
\hline & \multicolumn{2}{|c|}{ Carbon dioxide Emission $\mathrm{CO}_{2}$ produced by loss } & \\
\hline & $\mathrm{CW}_{\mathrm{nf}}$ & $\begin{array}{l}\text { Loss Carbon dioxide emission of } \\
\text { produce } n \text { at farmer }\end{array}$ & \\
\hline & $\mathrm{CW}_{\mathrm{ng}}$ & $\begin{array}{l}\text { Loss Carbon dioxide emission of } \\
\text { produce } n \text { at agent }\end{array}$ & \\
\hline & $\mathrm{CW}_{\text {na }}$ & $\begin{array}{l}\text { Loss Carbon dioxide emission of } \\
\text { produce } n \text { at auctioneer }\end{array}$ & \\
\hline & $\mathrm{CW}_{\mathrm{nl}}$ & $\begin{array}{l}\text { Loss Carbon dioxide emission of } \\
\text { produce } n \text { at whole seller }\end{array}$ & \\
\hline & $\mathrm{CW}_{\mathrm{nr}}$ & $\begin{array}{l}\text { Loss Carbon dioxide emission of } \\
\text { produce } n \text { at retail }\end{array}$ & \\
\hline
\end{tabular}

Loss Carbon dioxide emission of produce $n$ at agent

Loss Carbon dioxide emission of produce $n$ from Farmer to auctioneer Loss Carbon dioxide emission of produce $n$ from farmer to whole seller

Loss Carbon dioxide emission of produce $n$ from farmer to retail store Loss Carbon dioxide emission of produce $n$ from farmer to customer Loss Carbon dioxide emission of produce $n$ from agent to auctioneer Loss Carbon dioxide emission of produce $n$ from agent to whole seller Loss Carbon dioxide emission of produce $n$ from agent to retail store Loss Carbon dioxide emission of produce $n$ from agent to customer Carbon dioxide emission of produce $n$ from auctioneer to whole seller Carbon dioxide emission of produce $n$ from auctioneer to retail store Carbon dioxide emission of produce $n$ from auctioneer to customer Loss Carbon dioxide emission of produce $n$ from whole seller to retail store

Loss Carbon dioxide emission of produce $n$ from whole seller to customer Loss Carbon dioxide emission of produce $n$ from retail to customer

\section{Introduction}

As the population increases, agriculture production and supply must increase to meet the increasing demand (Alexandratos and Bruinsma, 2012). In a supply chain (SC), increasing demand can be satisfied only by efficient logistics (Lummus et al., 2001). Hence, agriculture commodity has to be transported efficiently from farmers to the consuming regions, where agriculture supply chain management (ASCM) plays a prominent role (Ahumada and Villalobos, 2009; Etemadnia et al., 2015). Traditionally, ASCM is viewed as a process where the agricultural produces are converted into value-added final products, and then delivered to the consumer and this process involves harvesting and consumption of the natural resources (Beamon, 1999). It is consequential to note that environmental sustainability and food security have become important issues to business practice (Kumar and Chandrakar, 2012). 
The strategy of improving environmental quality reduces poverty, and brings about economic growth, with resultant improvements in health (Bhateja et al., 2011; Jang and Klein, 2011). According to Syahruddin and Kalchschmidt (2011), in recent years, several measures have been made toward improving environmental hazards in ASCM in the developed countries, with the developing countries like India are yet to initiate this process. The Indian ASCM ignores some of the important issues like environmental damage, food safety, social and sustainability issues, which are driven by external factors such as customer and market demand (Syahruddin and Kalchschmidt, 2011). The environmental issues of ASCM are caused by the post-harvest losses (PHL) occurring at various levels of the SC (Hodges et al., 2011).

If the PHL are reduced, then the cost of agriculture produces will reduce instantly (Murthy et al., 2007). Around 30-40 percent of total produce gets wasted in India due to improper ASCM (Negi and Anand, 2015b). These PHL cannot be reduced without improving the infrastructure and awareness of the intermediaries in the ASCM on PHL (Parfitt et al., 2010; Ratinger, 2013). Therefore, it is most important to plan the supply and estimate PHL quantity at every level in the agricultural SC. The supply and PHL quantity of Indian traditional ASCM can be optimized and planned by mathematical modeling (Mula et al., 2010).

The mathematical model of Indian traditional ASCM is complicated, because intermediaries increased the echelon of traditional ASCM (Dalei and Dutta, 2015). Figure 1 shows the self-descriptive way of traditional ASCM that concise of many intermediaries and direct market. The purpose of this paper is to construct an optimum mathematical planning model for complex Indian traditional ASCM, and adopt a meta-heuristic genetic algorithm (GA) to solve this model. The objectives of this paper are to optimize the supply structure to reduce PHL and modify the transportation method to reduce the environmental impacts.

\section{Literature review}

In the recent years, there has been an increased attention in using GA to solve single- and multi-objective problems in production and operations management (Dimopoulos and Zalzala, 2000). GA is chosen as it is the most popular meta-heuristic algorithm within the context of SC planning and optimization (Fahimnia et al., In press). This paper uses the GA as a meta-heuristic algorithm to optimize the supply structure of the Indian ASCM to reduce the PHL. According to Shukla and Jharkharia (2013), very little attention is given to the reduction of PHL. They listed various factors affecting ASCM as globalization, technological innovations, trade agreements, consumer awareness, environmental concerns, etc. In addition to that the PHL transpires due to many intermediaries. The PHL occur in the ASCM because they relate to wasteful behavior of intermediaries, retailers and customers (Parfitt et al., 2010; Gustavsson et al., 2011).

Elimination of intermediaries from the ASCM will improve its efficiency (Jansen, 1996). However, few authors (Klerkx and Leeuwis, 2008; Amrutlal, 2010) suggested to integrate the intermediaries in ASCM to optimize their supply structure. Therefore, in this research paper, intermediaries are retained for SC modeling for optimizing the SC while estimating the PHL and its $\mathrm{CO}_{2}$ emission. Since recent years, many researchers have been focusing on environmental sustainability (Vorst et al., 2010) because the agriculture sector is contributing 14 percent in total toward global $\mathrm{CO}_{2}$ emissions (UNEP, 2012); if the agriculture sector's emission gets reduced, consequently, the overall emission will reduce (Blok et al., 2001). The $\mathrm{CO}_{2}$ emission sources in the agriculture sector are direct emission and indirect emission (Schils et al., 2005).

The emission of $\mathrm{CO}_{2}$ by the produces or land use is direct emission and the emission of $\mathrm{CO}_{2}$ by the fuel burnt during transportation is indirect emission (Schils et al., 2005). Indirect emission by the fuel burnt during transportation has attracted attention from many agriculture and automobile researchers. The less concentrated area in indirect emission 
IMDS

117,9

1822

Figure 1.

Indian agriculture marketing

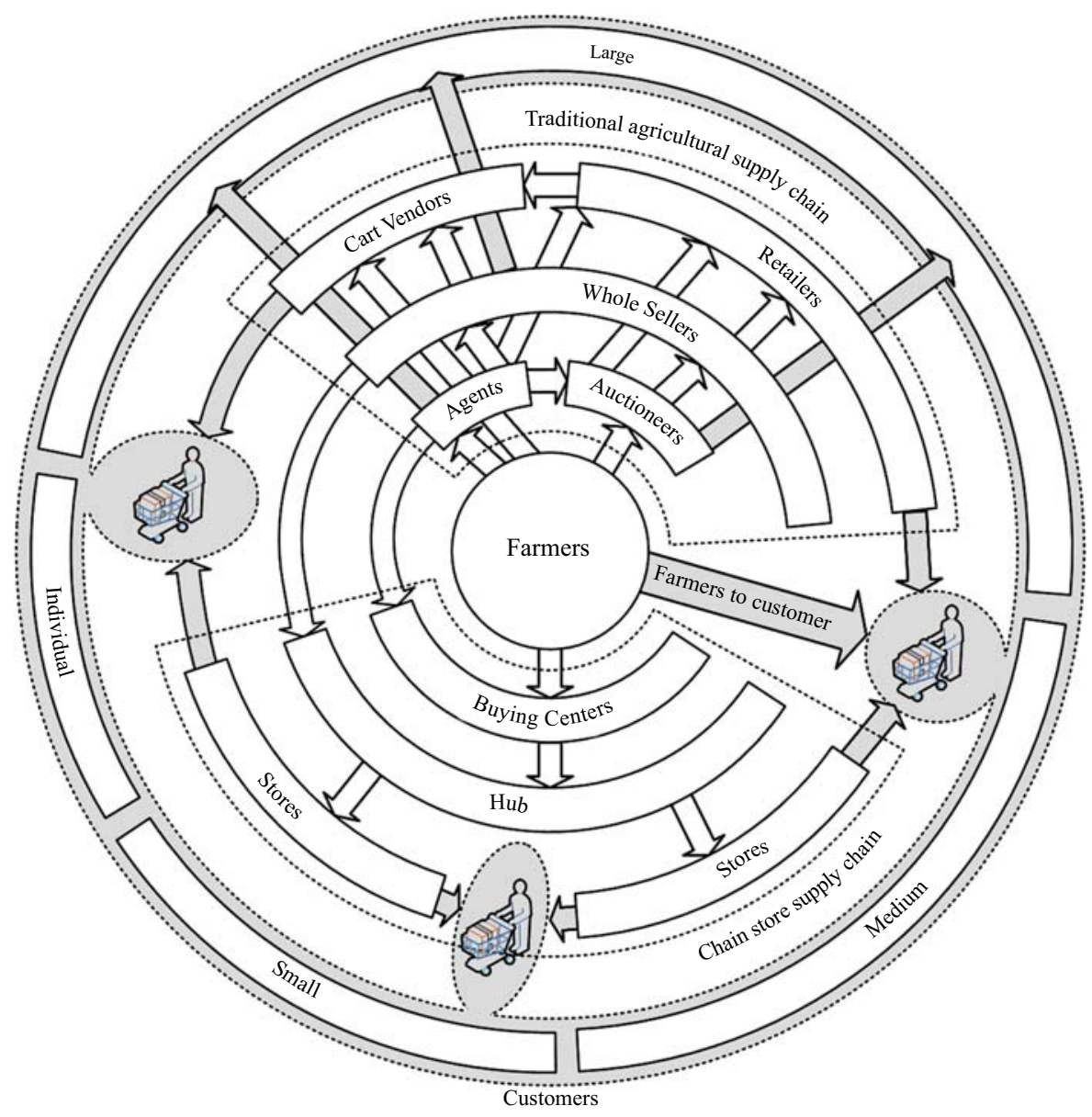

includes respiration releases of $\mathrm{CO}_{2}$ after produces have been harvested (Blok et al., 2001). Proper packing can maintain the quality of the produce as the $\mathrm{CO}_{2}$ generated while packing is at an elevated level (Kader and Rolle, 2004). All agriculture produces should be properly packed before transportation.

\subsection{Indian agriculture $S C$}

The Indian ASCM has become more complex and improper due to the imbalance between demand and supply (Joshi et al., 2009). This complexity of ASCM and improper handling by the intermediaries plays a major role in ASCM and its PHL (Negi and Anand, 2015b). However, Indian traditional ASCM has more potential to satisfy the demand than a chain store SC; hence, it needs more research concentration (Bala, 2014). Figure 1 shows that Indian ASCM consists of two SCs: first is private retailers following the chain store SC, and second is traditional ASCM which includes many intermediaries like agents, auctioneers, wholesalers and retailers (Gigler et al., 2002; Negi and Anand, 2015a, b).

The produces, which are produced by the Indian farmers, take two possible routes, namely, the agents and auctioneers, and from there, produces move to customer through 
whole sellers and retailers. This method is called traditional ASCM. Alternatively, depending on the quantity and cost, the produces may change the route to reach the customer directly through whole sellers and retailers in traditional ASCM (Negi and Anand, 2015a, b). The most efficient and less-practiced route is the direct market. In direct market, the produces reach the customer directly without any intermediaries like agents, auctioneers, whole sellers and retailers (Rajkumar and Jacob, 2010). The Indian farmers mostly practice traditional ASCM, which supply the agriculture products to the consumer through the intermediaries (Bahinipati, 2014).

The past research works clearly indicate the need for planning and optimizing the Indian ASCM. Since Indian agriculture transportation transports the produces through open craters (FAO, 2005; Vigneault et al., 2009; Bhushan, 2013), it leads to continuous emission of $\mathrm{CO}_{2}$ through respiration of the agricultural produces (Snowden, 2010). Therefore, this paper identifies an alternate transportation method to reduce the $\mathrm{CO}_{2}$ emission and investigates PHL from field to plate of selected agriculture produces.

\section{Adopted approach}

The Indian traditional ASCM is modeled by considering all intermediaries and assumes $\mathrm{PHL}$ in various percentages. The percentages of PHL of different produces were estimated by many researchers such as Gangwar et al. (2007) and Sharma and Singh (2011). Those PHL percentages lie in between 10 and 50 percent. Therefore, the assumed percentage of losses at the first level of ASCM is 10 percent, and ends at 50 percent with an increment of 10 percent, because 10 is the lowest percentage of loss and 50 is the highest percentage of loss. In this paper, loss is nothing but non-consumed produces, which is a previous stage of degradation. According to respiration the degraded and non-consumed produces are different. Respiration was measured through the experimental setup to calculate the $\mathrm{CO}_{2}$ emission as shown in Figure 3.

The $\mathrm{CO}_{2}$ emitted by agricultural produces through the respiration was estimated for those PHL and also the $\mathrm{CO}_{2}$ emissions of all undamaged supplied products were measured. The respiration of selected agriculture produces was measured in the non-degraded condition of the produce. The agricultural produces like potato and tomato were purposively selected based on their compatibility with ASCM and availability. The $\mathrm{CO}_{2}$ evolutions of potato and tomato were measured using the respiration to estimate the respiration rate. The $\mathrm{CO}_{2}$ evolution is applied to the overall production of respective produces to measure the overall $\mathrm{CO}_{2}$ emission. These $\mathrm{CO}_{2}$ evolutions were applied to the PHL quantity to measure its $\mathrm{CO}_{2}$ emission. Therefore, this research paper formulates a mathematical model to plan the supply, estimate $\mathrm{PHL}$ and $\mathrm{CO}_{2}$ emission for various optimized supplies.

\subsection{Loss and emission source proposed model}

Many PHL are available in this traditional ASCM like packing and transportation (Gigler et al., 2002; Sharma and Singh, 2011); these PHL were intended by a mathematical model along with overall losses and loss of $\mathrm{CO}_{2}$ emission. Figure 2 classifies Indian traditional ASCM into five different $\mathrm{SC}$ models and shows the PHL and $\mathrm{CO}_{2}$ emission sources at every level. PHL are shown in Figure 2 as loss, which happens during transportation. In addition, there are two $\mathrm{CO}_{2}$ emission sources considered in this paper which are unconsumed and fresh produces emission.

Therefore, the PHL and $\mathrm{CO}_{2}$ emissions are high in ASCM due to the presence of multiple supply stages or the presence of intermediaries such as agents, auctioneers, whole sellers, and retailers. The produces are transported from farmer to customer through these intermediaries by open transportation in trucks (Ashby, 2008; Rajkumar and Jacob, 2010). As proper loading and unloading is not followed in the open truck transportation (Vigneault et al., 2009), it leads to exploitation of farmers by the intermediaries (Ashby, 2008; Rajkumar and Jacob, 2010). 


\section{IMDS}

117,9

\section{4}

Figure 2.

Different traditional agriculture supply chain

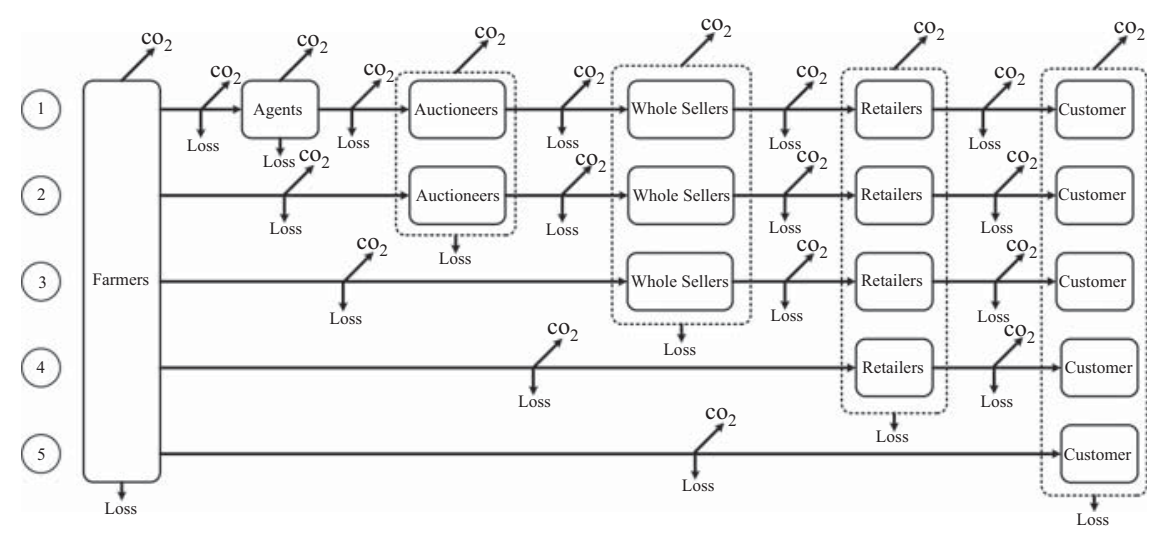

The agricultural produces respire continuously during open truck transportation. The produces start respiration immediately after harvest until it is consumed or degraded. The static and closed method is used to measure the $\mathrm{CO}_{2}$ emission released by produces during respiration (Yahia, 2009). Experiments were conducted individually and also mixed together to know how much $\mathrm{CO}_{2}$ is produced. During this experiment, the produces are experimented in a closed container and respired for six hours.

\subsection{Experimental setup}

The agriculture produces are selected based on local production and are grouped based on their storage properties. The $\mathrm{O}_{2}$ consumption and $\mathrm{CO}_{2}$ evolution are measured by the static method in atmospheric temperature without any external aid. The static method can measure the respiration in a closed container (Fonseca et al., 2002). The respiration of the selected agriculture produces is measured by gas sensors for the sample time of one hour and six hours. In this static method, the relative humidity of the selected produces for the reason of respiration produces water droplets after six hours; therefore, the experiments were conducted for six hours.

The sensors used in this experiment are the Vernier $\mathrm{O}_{2}$ sensor in the range of 0-27 percent (0-270 ppt), the Vernier $\mathrm{CO}_{2}$ sensor in the low range: 0 to $10,000 \mathrm{ppm}$ and high range: 0 to $100,000 \mathrm{ppm}$, the Vernier relative humidity sensor in the range of 0 to 95 percent, and the $t$-type thermocouple in the range of 0 to $350^{\circ} \mathrm{C}$. These sensors were interfaced with a computer through national instrument ELVIS II. Figure 3 shows the experimental setup. The $\mathrm{O}_{2}$ sensor value changes with respect to the relative humidity value; therefore, the relative humidity was measured for $\mathrm{O}_{2}$ sensor. Two produces, namely, potato and tomato were selected to measure their respiration levels as individual produces as well as mixed quantities were studied for their $\mathrm{O}_{2}$ consumption and $\mathrm{CO}_{2}$ evolution.

Initially, the individual agriculture produces' respiration rates were measured by the experimental setup as shown in Figure 3. In addition, two vegetables were combined and measured by this experimental setup. The agricultural produces like potato, tomato, and their combinations were experimented in the weight of 100, 200, and $300 \mathrm{~g}$. Mixing of samples was based on produce selection and their compatibility. This comparative study of individual and mixed produces shows the $\mathrm{CO}_{2}$ evolution variations along with $\mathrm{O}_{2}$ consumption. Through this way, the $\mathrm{CO}_{2}$ respiration rate was averaged and measured. Subsequently, those values were applied in the mathematical model to estimate the supply, transport loss quantity and $\mathrm{CO}_{2}$ emission. 


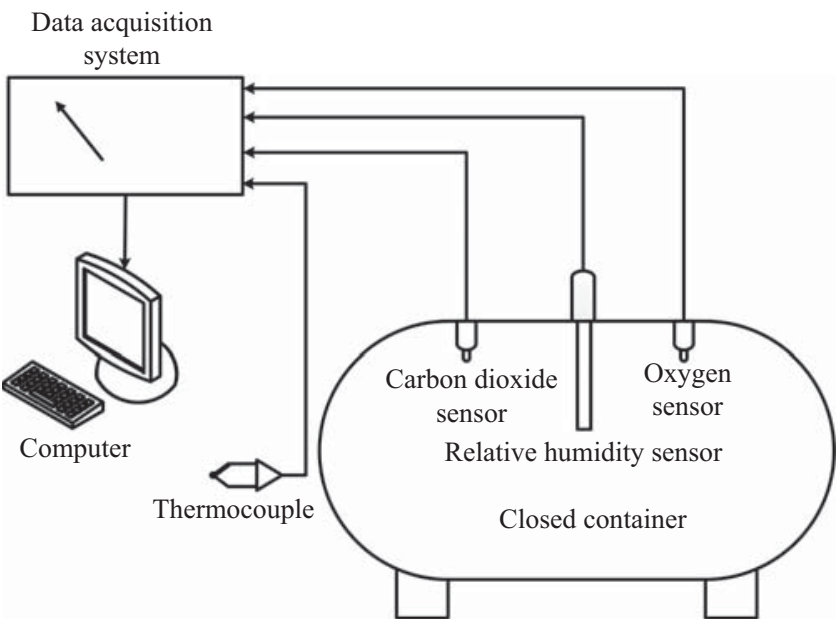

\section{Indian \\ traditional \\ agriculture \\ supply chain}

1825

\subsection{Model description}

An SC planning model is used here to optimize the supply between each stage and estimate the loss and $\mathrm{CO}_{2}$ emission. This planning model considered that the demand $D_{n}$ of the $n$th produce is equal to the farmer's production. Succeedingly, $Q_{n}$ is the capacity or supply of any stage of the $n$th produce. Likewise, $T_{n}, W_{n}$, and $C_{n}$ are the transport, loss quantity and $\mathrm{CO}_{2}$ emission of the $n$th produce of the concerned stage, respectively. The decision variables are the percentage of supply $\left(\mathrm{PQ}_{n}\right)$ and loss $\left(\mathrm{PW}_{n}\right)$ quantities, which decide the efficiency of the whole SC in this model. The decision variables are in percentage so that they can estimate the value from the production quantity.

These decision variables are used to calculate the quantity supply and quantity loss at each stage. Equation (1) can estimate the loss at the farmer's end by applying the farmer's loss percentage $\mathrm{PW}_{\mathrm{nf}}$, and then the supply capacity of the farmers can be measured by Equation (2). Likewise, the supply capacity of agents, auctioneers, whole sellers and retailers can be measured by Equations (3)-(6), respectively. Equations (7) to (21) measure the supply quantities of each stage to other consequent stages. The total supply quantities were estimated by summing all the supply quantities; likewise, the total loss quantities were estimated by adding all the loss quantities. The loss quantities can be measured by Equations (36) to (53). If the loss is eliminated from the previous supply quantity, then that is nothing but the transported quantity $\left(T_{n}\right)$.

Equations (22) to (35) calculate transported quantities between each stage. The transported quantities were used to measure the total quantity transported and total transportation losses. The total loss and supply quantities are shown in (54) and (55), respectively. The total $\mathrm{CO}_{2}$ consumption of loss quantities can be measured by Equation (56). The total supply and loss quantities were large in size; therefore, those large equations were solved algebraically by the MATLAB software package. The supply quantity needs to be optimized to gain higher supply and lower losses. The supply quantity is optimized through GA. Equations (57) to (69) are constraints for the models. In that first five equations are nonlinear constraints. Second five equations are linear constraints and remaining equations are upper and lower bound.

The first five nonlinear equations are the sum of all the supply quantities, which are supplied from the farmer to other stages and should be equal to the total demand or production. In the second five equations, the quantities which are supplied from the farmer to other stages should be greater than supply quantities of each stage to other stages. 
IMDS

117,9

1826

The supply quantity which is supplied by the retailer to the customer should be less than the sum of supply quantities of the farmer to the retailer and other stages to the customer. In linear equations, first is the sum of all the percentages of supply quantities supplied from the farmer to other stages which should be equal to 100; likewise, the remaining percentage of supply quantities, supplied from each stage to other stages, should be less than or equal to 100. Finally, the bound constraints should be defined for all the objectives while solving an objective using GA.

There are three bound constraints: loss, supply and $\mathrm{CO}_{2}$ emission. These three constraints should be greater than 0; likewise, the loss should be less than demand, the supply should be less than or equal to demand, and $\mathrm{CO}_{2}$ emission should be less than the overall emission. Based on the above constraints, the supply structure of Indian TASCM is optimized. These optimized supply structures are shown in Table I. The loss, supply and $\mathrm{CO}_{2}$ emission quantities are estimated by Equations (54)-(56), respectively, based on the optimized supply structure:

$$
\begin{gathered}
W_{\mathrm{nf}}=D_{n} \times \mathrm{PW}_{\mathrm{nf}} \\
Q_{\mathrm{nf}}=D_{n}-W_{\mathrm{nf}} \\
Q_{\mathrm{ng}}=T_{\mathrm{nfg}}-W_{\mathrm{ng}} \\
Q_{\mathrm{na}}=\left[T_{\mathrm{nfa}}+T_{\mathrm{nga}}\right]-W_{\mathrm{na}} \\
Q_{\mathrm{nl}}=\left[T_{\mathrm{nfl}}+T_{\mathrm{ngl}}+T_{\mathrm{nal}}\right]-W_{\mathrm{nl}} \\
Q_{\mathrm{nr}}=\left[T_{\mathrm{nfr}}+T_{\mathrm{ngr}}+T_{\mathrm{nar}}+T_{\mathrm{nlr}}\right]-W_{\mathrm{nr}} \\
Q_{\mathrm{nfg}}=Q_{\mathrm{nf}} \times \mathrm{PQ}_{\mathrm{nfg}} \\
Q_{\mathrm{nfa}}=Q_{\mathrm{nf}} \times \mathrm{PQ}_{\mathrm{nfa}}
\end{gathered}
$$

\begin{tabular}{lccc}
\hline & & Supply structures \\
Type-1 in $\%$ & Type-2 in $\%$ & Type-3 in \% \\
\hline $\mathrm{PQ}_{\text {nfg }}$ & 20 & 20 & 0 \\
$\mathrm{PQ}_{\text {nfa }}$ & 20 & 20 & 0 \\
$\mathrm{PQ}_{\text {nfl }}$ & 20 & 20 & 0 \\
$\mathrm{PQ}_{\text {nfr }}$ & 20 & 20 & 0 \\
$\mathrm{PQ}_{\text {nfe }}$ & 20 & 20 & 100 \\
$\mathrm{PQ}_{\text {nga }}$ & 25 & 0 & 0 \\
$\mathrm{PQ}_{\text {ngl }}$ & 25 & 0 & 0 \\
$\mathrm{PQ}_{\text {ngr }}$ & 25 & 0 & 0 \\
$\mathrm{PQ}_{\text {nge }}$ & 25 & 100 & 0 \\
$\mathrm{PQ}_{\text {nal }}$ & 30 & 0 & 0 \\
$\mathrm{PQ}_{\text {nar }}$ & 30 & 0 & 0 \\
$\mathrm{PQ}_{\text {nae }}$ & 40 & 100 & 0 \\
$\mathrm{PQ}_{\text {nlr }}$ & 50 & 0 & 0 \\
$\mathrm{PQ}_{\text {nle }}$ & 50 & 0 & 0 \\
$\mathrm{PQ}_{\text {nre }}$ & 100 & 100 & 0 \\
\hline
\end{tabular}

Table I.

Supply structures 


$$
\begin{aligned}
& Q_{\mathrm{nfl}}=Q_{\mathrm{nf}} \times \mathrm{PQ}_{\mathrm{nfl}} \\
& Q_{\mathrm{nfr}}=Q_{\mathrm{nf}} \times \mathrm{PQ}_{\mathrm{nfr}} \\
& Q_{\text {nfe }}=Q_{\text {nf }} \times \mathrm{PQ}_{\mathrm{nfe}} \\
& Q_{\text {nga }}=Q_{\text {ng }} \times \mathrm{PQ}_{\text {nga }} \\
& Q_{\mathrm{ngl}}=Q_{\mathrm{ng}} \times \mathrm{PQ}_{\mathrm{ng} \mathrm{l}} \\
& Q_{\mathrm{ngr}}=Q_{\mathrm{ng}} \times \mathrm{PQ}_{\mathrm{ngr}} \\
& Q_{\text {nge }}=Q_{\text {ng }} \times \mathrm{PQ}_{\text {nge }} \\
& Q_{\text {nal }}=Q_{\text {na }} \times \mathrm{PQ}_{\text {nal }} \\
& Q_{\text {nar }}=Q_{\text {na }} \times \mathrm{PQ}_{\text {nar }} \\
& Q_{\text {nae }}=Q_{\text {na }} \times \mathrm{PQ}_{\text {nae }} \\
& Q_{\mathrm{nlr}}=Q_{\mathrm{nl}} \times \mathrm{PQ}_{\mathrm{nlr}} \\
& Q_{\text {nle }}=Q_{\mathrm{nl}} \times \mathrm{PQ}_{\mathrm{nle}} \\
& Q_{\text {nre }}=Q_{\mathrm{nr}} \times \mathrm{PQ}_{\mathrm{nre}} \\
& T_{\mathrm{nfg}}=Q_{\mathrm{nfg}}-W_{\mathrm{nfg}} \\
& T_{\mathrm{nfa}}=Q_{\mathrm{nfa}}-W_{\mathrm{nfa}} \\
& T_{\mathrm{nfl}}=Q_{\mathrm{nfl}}-W_{\mathrm{nfl}} \\
& T_{\mathrm{nfr}}=Q_{\mathrm{nfr}}-W_{\mathrm{nfr}} \\
& T_{\text {nfe }}=Q_{\text {nfe }}-W_{\text {nfe }} \\
& T_{\text {nga }}=Q_{\text {nga }}-W_{\text {nga }} \\
& T_{\mathrm{ngl}}=Q_{\mathrm{ngl}}-W_{\mathrm{ngl}} \\
& T_{\text {ngr }}=Q_{\text {ngr }}-W_{\text {ngr }} \\
& T_{\text {nge }}=Q_{\text {nge }}-W_{\text {nge }}
\end{aligned}
$$


IMDS

117,9

1828

$$
\begin{aligned}
& T_{\text {nal }}=Q_{\text {nal }}-W_{\text {nal }} \\
& T_{\text {nar }}=Q_{\text {nar }}-W_{\text {nar }} \\
& T_{\text {nae }}=Q_{\text {nae }}-W_{\text {nae }} \\
& T_{\mathrm{nlr}}=Q_{\mathrm{nlr}}-W_{\mathrm{nlr}} \\
& T_{\text {nle }}=Q_{\text {nle }}-W_{\text {nle }} \\
& W_{\mathrm{ng}}=T_{\mathrm{nfg}} \times \mathrm{PW}_{\mathrm{ng}} \\
& W_{\text {na }}=\left[T_{\text {nfa }}+T_{\text {nga }}\right] \times \mathrm{PW}_{\text {na }} \\
& W_{\mathrm{nl}}=\left[T_{\mathrm{nfl}}+T_{\mathrm{ngl}}+T_{\mathrm{nal}}\right] \times \mathrm{PW}_{\mathrm{nl}} \\
& W_{\mathrm{nr}}=\left[T_{\mathrm{nfr}}+T_{\mathrm{ngr}}+T_{\mathrm{nar}}+T_{\mathrm{nlr}}\right] \times \mathrm{PW}_{\mathrm{nr}} \\
& W_{\mathrm{nfg}}=Q_{\mathrm{nfg}} \times \mathrm{PW}_{\mathrm{nfg}} \\
& W_{\text {nfa }}=Q_{\text {nfa }} \times \mathrm{PW}_{\mathrm{nfa}} \\
& W_{\mathrm{nfl}}=Q_{\mathrm{nfl}} \times \mathrm{PW}_{\mathrm{nfl}} \\
& W_{\mathrm{nfr}}=Q_{\mathrm{nfr}} \times \mathrm{PW}_{\mathrm{nfr}} \\
& W_{\text {nfe }}=Q_{\text {nfe }} \times \mathrm{PW}_{\text {nfe }} \\
& W_{\text {nga }}=Q_{\text {nga }} \times \mathrm{PW}_{\text {nga }} \\
& W_{\mathrm{ngl}}=Q_{\mathrm{ngl}} \times \mathrm{PW}_{\mathrm{ngl}} \\
& W_{\text {ngr }}=Q_{\text {ngr }} \times \mathrm{PW}_{\text {ngr }} \\
& W_{\text {nge }}=Q_{\text {nge }} \times \mathrm{PW}_{\text {nge }} \\
& W_{\text {nal }}=Q_{\text {nal }} \times \mathrm{PW}_{\text {nal }} \\
& W_{\text {nar }}=Q_{\text {nar }} \times \mathrm{PW}_{\text {nar }} \\
& W_{\text {nae }}=Q_{\text {nae }} \times \mathrm{PW}_{\text {nae }}
\end{aligned}
$$




$$
\begin{aligned}
& W_{\text {nlr }}=Q_{\text {nlr }} \times \mathrm{PW}_{\mathrm{nlr}} \\
& W_{\text {nle }}=Q_{\text {nle }} \times \mathrm{PW}_{\text {nle }}
\end{aligned}
$$

Objective 1 - total loss:

$$
\begin{aligned}
\min f(W)= & \sum_{n} \sum_{f} W_{\mathrm{nf}}+\sum_{n} \sum_{g} W_{\mathrm{ng}}+\sum_{n} \sum_{a} W_{\mathrm{na}}+\sum_{n} \sum_{l} W_{\mathrm{nl}}+\sum_{n} \sum_{r} W_{\mathrm{nr}} \\
& +\sum_{n} \sum_{f} \sum_{g} W_{\mathrm{nfg}}+\sum_{n} \sum_{f} \sum_{a} W_{\mathrm{nfa}}+\sum_{n} \sum_{f} \sum_{l} W_{\mathrm{nfl}} \\
& +\sum_{n} \sum_{f} \sum_{r} W_{\mathrm{nfr}}+\sum_{n} \sum_{f} \sum_{e} W_{\mathrm{nfe}}+\sum_{n} \sum_{g} \sum_{a} W_{\mathrm{nga}} \\
& +\sum_{n} \sum_{g} \sum_{l} W_{\mathrm{ngl}}+\sum_{n} \sum_{g} \sum_{r} W_{\mathrm{ngr}}+\sum_{n} \sum_{g} \sum_{e} W_{\mathrm{nge}} \\
& +\sum_{n} \sum_{a} \sum_{l} W_{\mathrm{nal}}+\sum_{n} \sum_{a} \sum_{r} W_{\mathrm{nar}}+\sum_{n} \sum_{a} \sum_{e} W_{\mathrm{nae}} \\
& +\sum_{n} \sum_{l} \sum_{r} W_{\mathrm{nlr}}+\sum_{n} \sum_{l} \sum_{e} W_{\mathrm{nle}}+\sum_{n} \sum_{r} \sum_{e} W_{\mathrm{nre}}
\end{aligned}
$$

Objective 2 - total supply:

$$
\begin{aligned}
\max f(Q)= & \sum_{n} \sum_{f} Q_{\mathrm{nf}}+\sum_{n} \sum_{g} Q_{\mathrm{ng}}+\sum_{n} \sum_{a} Q_{\mathrm{na}}+\sum_{n} \sum_{l} Q_{\mathrm{nl}}+\sum_{n} \sum_{r} Q_{\mathrm{nr}} \\
& +\sum_{n} \sum_{f} \sum_{g} Q_{\mathrm{nfg}}+\sum_{n} \sum_{f} \sum_{a} Q_{\mathrm{nfa}}+\sum_{n} \sum_{f} \sum_{l} Q_{\mathrm{nfl}}+\sum_{n} \sum_{f} \sum_{r} Q_{\mathrm{nfr}} \\
& +\sum_{n} \sum_{f} \sum_{e} Q_{\mathrm{nfe}}+\sum_{n} \sum_{g} \sum_{a} Q_{\mathrm{nga}}+\sum_{n} \sum_{g} \sum_{l} Q_{\mathrm{ngl}}+\sum_{n} \sum_{g} \sum_{r} Q_{\mathrm{ngr}} \\
& +\sum_{n} \sum_{g} \sum_{e} Q_{\mathrm{nge}}+\sum_{n} \sum_{a} \sum_{l} Q_{\mathrm{nal}}+\sum_{n} \sum_{a} \sum_{r} Q_{\mathrm{nar}}+\sum_{n} \sum_{a} \sum_{e} Q_{\mathrm{nae}} \\
& +\sum_{n} \sum_{l} \sum_{r} Q_{\mathrm{nlr}}+\sum_{n} \sum_{l} \sum_{e} Q_{\mathrm{nle}}+\sum_{n} \sum_{r} \sum_{e} Q_{\mathrm{nre}}
\end{aligned}
$$

Objective 3 - total carbon dioxide produced by loss:

$$
\begin{aligned}
\min f(\mathrm{CW})= & \sum_{n} \sum_{f} \mathrm{CW}_{\mathrm{nf}}+\sum_{n} \sum_{g} \mathrm{CW}_{\mathrm{ng}}+\sum_{n} \sum_{a} \mathrm{CW}_{\mathrm{na}}+\sum_{n} \sum_{l} \mathrm{CW}_{\mathrm{nl}} \\
& +\sum_{n} \sum_{r} \mathrm{CW}_{\mathrm{nr}}+\sum_{n} \sum_{f} \sum_{g} \mathrm{CW}_{\mathrm{nfg}}+\sum_{n} \sum_{f} \sum_{a} \mathrm{CW}_{\mathrm{nfa}} \\
& +\sum_{n} \sum_{f} \sum_{l} \mathrm{CW}_{\mathrm{nfl}}+\sum_{n} \sum_{f} \sum_{r} \mathrm{CW}_{\mathrm{nfr}}+\sum_{n} \sum_{f} \sum_{e} \mathrm{CW}_{\mathrm{nfe}} \\
& +\sum_{n} \sum_{g} \sum_{a} \mathrm{CW}_{\mathrm{nga}}+\sum_{n} \sum_{g} \sum_{l} \mathrm{CW}_{\mathrm{ngl}}+\sum_{n} \sum_{g} \sum_{r} \mathrm{CW}_{\mathrm{ngr}} \\
& +\sum_{n} \sum_{g} \sum_{e} \mathrm{CW}_{\mathrm{nge}}+\sum_{n} \sum_{a} \sum_{l} \mathrm{CW}_{\mathrm{nal}}+\sum_{n} \sum_{a} \sum_{r} \mathrm{CW}_{\mathrm{nar}}
\end{aligned}
$$


IMDS

117,9

$$
\begin{aligned}
& +\sum_{n} \sum_{a} \sum_{e} \mathrm{CW}_{\mathrm{nae}}+\sum_{n} \sum_{l} \sum_{r} \mathrm{CW}_{\mathrm{nlr}}+\sum_{n} \sum_{l} \sum_{e} \mathrm{CW}_{\mathrm{nle}} \\
& +\sum_{n} \sum_{r} \sum_{e} \mathrm{CW}_{\mathrm{nre}}
\end{aligned}
$$

1830

Nonlinear constraints:

$$
\begin{gathered}
Q_{\mathrm{nfg}}+Q_{\mathrm{nfa}}+Q_{\mathrm{nfl}}+Q_{\mathrm{nfr}}+Q_{\mathrm{nfe}}=D_{n} \\
Q_{\mathrm{nga}}+Q_{\mathrm{ngl}}+Q_{\mathrm{ngr}}+Q_{\mathrm{nge}} \leqslant Q_{\mathrm{nfg}} \\
Q_{\mathrm{nal}}+Q_{\mathrm{nar}}+Q_{\mathrm{nae}} \leqslant Q_{\mathrm{nfa}}+Q_{\mathrm{nga}} \\
Q_{\mathrm{nlr}}+Q_{\mathrm{nle}} \leqslant Q_{\mathrm{nfl}}+Q_{\mathrm{ngl}}+Q_{\mathrm{nal}} \\
Q_{\mathrm{nre}} \leqslant Q_{\mathrm{nfr}}+Q_{\mathrm{nge}}+Q_{\mathrm{nae}}+Q_{\mathrm{nle}}
\end{gathered}
$$

Linear constraints:

$$
\begin{gathered}
\mathrm{PQ}_{\mathrm{nfg}}+\mathrm{PQ}_{\mathrm{nfa}}+\mathrm{PQ}_{\mathrm{nfl}}+\mathrm{PQ}_{\mathrm{nfr}}+\mathrm{PQ}_{\mathrm{nfe}}=100 \\
\mathrm{PQ}_{\mathrm{nga}}+\mathrm{PQ}_{\mathrm{ngl}}+\mathrm{PQ}_{\mathrm{ngr}}+\mathrm{PQ}_{\mathrm{nge}} \leqslant 100 \\
\mathrm{PQ}_{\mathrm{nal}}+\mathrm{PQ}_{\mathrm{nar}}+\mathrm{PQ}_{\text {nae }} \leqslant 100 \\
\mathrm{PQ}_{\mathrm{nlr}}+\mathrm{PQ}_{\mathrm{nle}} \leqslant 100 \\
\mathrm{PQ}_{\text {nre }} \leqslant 100
\end{gathered}
$$

Bound:

$$
\begin{gathered}
0 \leqslant W<D_{n} \\
0 \leqslant Q \leqslant D_{n} \\
0 \leqslant \mathrm{CW}<D_{n} \times C_{n}
\end{gathered}
$$

\subsection{Proposed GA}

Type 3 supply structure is optimized by GA. The GA solves the mathematical model using the MATLAB R2014a optimization tool box. The traditional optimization and search algorithms are not good enough to solve large SC problems (Kannan et al., 2010). So this research paper chooses the GA because this is inspired by biological evolution and works based on survival of the fittest. GA is the stochastic search algorithm that works iteratively on a population, carrying out a search directed by the fitness of each solution (Xie and Dong, 2002). This GA is more flexible with objective function and not depends on any priori hypotheses (Naso et al., 2007). In this paper, the optimization toolbox is used to run the GA solver. 
There are 13 decision variables in this modeling; the GA uses the binary decoding to proceed with the problem.

There are different terms that are specified for the purpose of optimization. Before specifying certain values for each of these terms, all of them were tested with regard to the accuracy of the results. The selected and used MATLAB prescribed terms in the GA toolbox for optimization are shown in the flow chart. The GA starts with defining objective function and constraints as described in Section 3.3. Then double vector population and constraint-dependent creation function were applied for constraints. The initial population, scores and ranges are not required to change from default values, because the feasible solution is obtained from default values. Rank scaling is applied, because ranking automatically introduces a uniform scaling across the population and also rank fitness scaling removes the effect of the spread of the raw scores.

Stochastic uniform reproduction is applied as a selection function, and then the default elite count and crossover fraction is applied in reproduction. The constraint-dependent crossover and mutation is applied, in addition to the optimization toolbox, which applies adaptive feasible mutation, when constraints were present; likewise. if linear constraints are present, then the optimization toolbox chooses intermediate crossover function. In terms of migration, the forward direction was applied with default fraction and interval. This optimization toolbox ends when the optimized supply structure is obtained; it is described in Section 4.1 (Figure 4).

\section{Results and discussions}

The mathematical model is used to plan an optimized supply structure to estimate loss and $\mathrm{CO}_{2}$ emission of Indian traditional ASCM. The previous researchers such as Gangwar et al. (2007) and Sharma and Singh (2011) calculated PHL for every level of ASCM, but they did

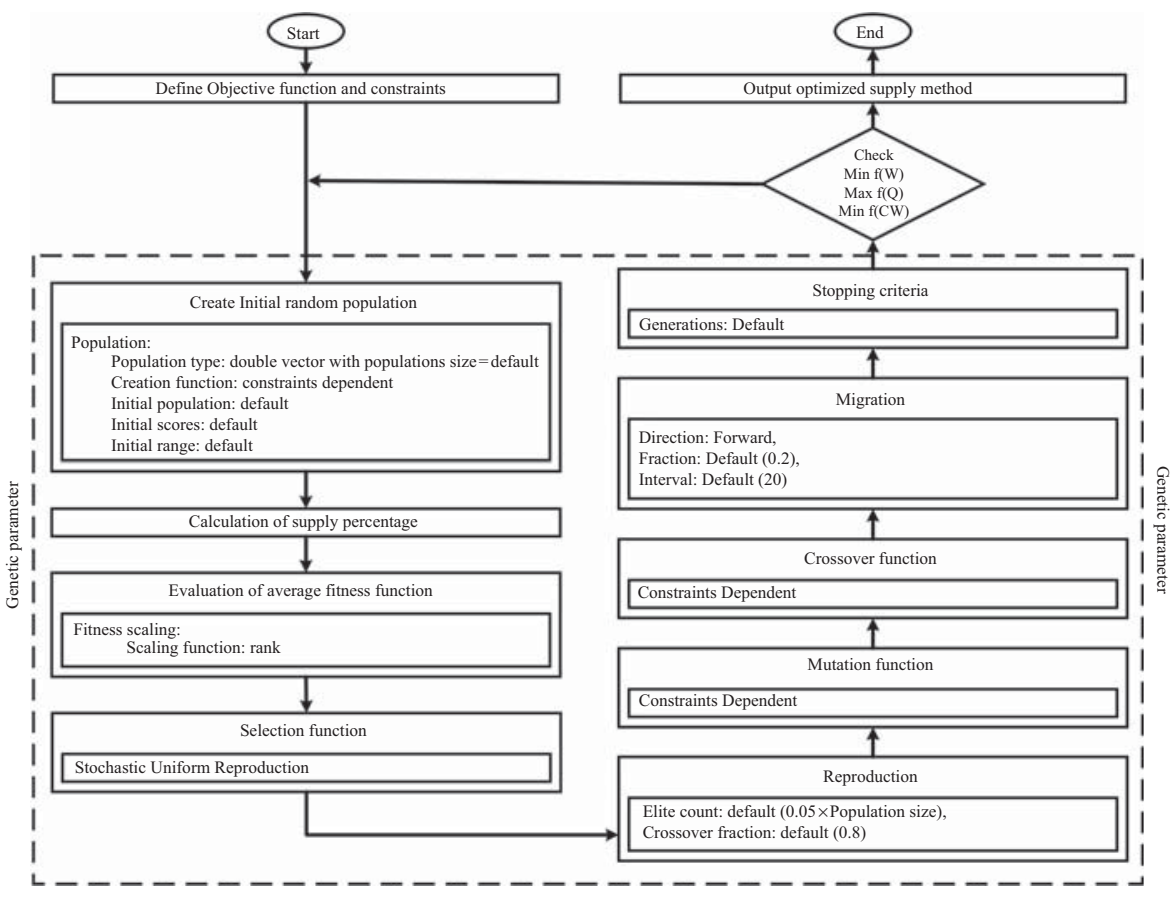

Figure 4.

Genetic algorithm flow chart 
IMDS 117,9

1832

not consider the environmental impacts. Therefore, the $\mathrm{CO}_{2}$ emissions of supply and loss were estimated through the respiration rate, which is measured for open and closed transportation of the selected produces such as potato, tomato and its combination.

\subsection{Optimization of supply}

This model is specifically used to plan the supply, estimate loss and $\mathrm{CO}_{2}$ emission by demand or production of produces. The 13 nomenclature and 36 decision variables are described in the topic of nomenclature. The decision variables are nothing but supply quantity percentage and loss quantity percentage at each of the stages. These percentages are the input for mathematical modeling to estimate the loss and $\mathrm{CO}_{2}$ emissions. The percentage of supply quantities of each stage like farmers to an agent is described in nomenclature and the values are shown in first column of Table I. The type 1, type 2 and type 3 columns are three different supply structures which are optimized.

The supply quantities are optimized through GA using the MATLAB R2014a optimization toolbox. Table I displays three optimized values which are called optimized supply structures. These supply structures are optimized to supply the agriculture produces to the customer through various stages. Among various supply structures, type 3 is the most optimized supply structure because this eliminates all the intermediaries. According to Neven et al. (2009) cooperative market is most efficient than other direct market or chain store market. Therefore, the supply structure type 1 is the most feasible option, because this method includes all the stages of ASCM. Succeeding, the supply structure type 2 supplies produces from the farmer to customer through other intermediaries directly, therefore this eliminates the supply between intermediaries.

These supply structures are applied in the mathematical model to calculate $\mathrm{PHL}$ and $\mathrm{CO}_{2}$ emission. The PHL was measured by assuming loss percentage and $\mathrm{CO}_{2}$ emissions were measured by measuring the respiration rate of produces and their group. The quantities of selected agriculture produces were identified and are shown in Table II. The agriculture produces have to be supplied to the customers to satisfy their demand without affecting the environment.

\subsection{Calculation of overall $\mathrm{CO}_{2}$ emission}

The respiration rates of $\mathrm{CO}_{2}$ of open and closed transportation were measured and shown in Table II. It comprises a year, production quantity of produces, as well as $\mathrm{CO}_{2}$ emission produced by respiration of agriculture produces during open and closed transportation. Succeeding that, the respiration rate of $\mathrm{CO}_{2}$ was applied to quantity of production to

\begin{tabular}{|c|c|c|c|c|c|c|c|}
\hline \multirow[b]{2}{*}{ Produces } & \multirow[b]{2}{*}{ Year } & \multirow{2}{*}{$\begin{array}{l}\text { Production } \\
\qquad \mathrm{In} \mathrm{Kg}\end{array}$} & \multicolumn{2}{|c|}{ Closed } & \multicolumn{2}{|c|}{ Open } & \multirow{2}{*}{$\begin{array}{l}\text { Difference } \\
\mathrm{ml} \mathrm{CO}_{2} / \mathrm{hr} \text {. }\end{array}$} \\
\hline & & & $\begin{array}{c}\text { Respiration } \\
\text { rate ml } \\
\mathrm{CO}_{2} / \mathrm{hr} \text {. }\end{array}$ & $\begin{array}{l}\mathrm{CO}_{2} \mathrm{ml} \\
\mathrm{CO}_{2} / \mathrm{hr} .\end{array}$ & $\begin{array}{c}\text { Respiration } \\
\text { rate ml } \\
\mathrm{CO}_{2} / \mathrm{hr} \text {. }\end{array}$ & $\begin{array}{l}\mathrm{CO}_{2} \mathrm{ml} \\
\mathrm{CO}_{2} / \mathrm{hr} .\end{array}$ & \\
\hline \multirow[t]{3}{*}{ Potato } & $2010-2011$ & $42,339,000$ & \multirow[t]{3}{*}{2.33} & $98,527,927$ & \multirow[t]{3}{*}{6.02} & $592,730,222$ & $494,202,295$ \\
\hline & $2011-2012$ & $41,483,000$ & & $96,535,912$ & & 580 & $484,210,629$ \\
\hline & 2012-2013 & $45,344,000$ & & $105,520,922$ & & $634,799,102$ & $529,278,180$ \\
\hline \multirow[t]{3}{*}{ Tomato } & $2010-2011$ & $16,826,000$ & \multirow[t]{3}{*}{5.24} & $88,188,945$ & \multirow[t]{3}{*}{18.21} & $1,605,948,799$ & $1,517,759,854$ \\
\hline & 2011-2012 & $18,653,000$ & & $97,764,673$ & & $1,780,325,862$ & $1,682,561,189$ \\
\hline & 2012-2013 & $18,227,000$ & & $95,531,909$ & & $1,739,666,514$ & $1,644,134,605$ \\
\hline \multirow{3}{*}{$\begin{array}{l}\text { Potato and } \\
\text { Tomato }\end{array}$} & 2010-2011 & $59,165,000$ & \multirow[t]{3}{*}{4.13} & $244,107,434$ & \multirow[t]{3}{*}{12.21} & $2,981,617,987$ & $2,737,510,553$ \\
\hline & 2011-2012 & $60,136,000$ & & $248,113,660$ & & $3,030,551,496$ & $2,782,437,837$ \\
\hline & 2012-2013 & $63,571,000$ & & $262,286,043$ & & $3,203,658,194$ & $2,941,372,152$ \\
\hline
\end{tabular}

Table II.

$\mathrm{CO}_{2}$ respiration rate and $\mathrm{CO}_{2}$ produced by respiration
Tomato 西 
estimate the overall $\mathrm{CO}_{2}$ emission. Both potato and tomato and their combination of respiration vary in open and closed transportation. The respiration rate is highly reduced, when potato and tomato are combined together in a closed transportation.

As referred to in Table II, potato has a rate of $6.02 \mathrm{ml} \mathrm{CO}_{2} / \mathrm{hr}$, tomato and its combination have respiration rates of $18.21 \mathrm{ml} \mathrm{CO}_{2} / \mathrm{hr}$ and $12.21 \mathrm{ml} \mathrm{CO} / \mathrm{hr}$, respectively, in open transportation. If the produces are transported in a closed container, then potato has a rate of $2.33 \mathrm{ml} \mathrm{CO} / \mathrm{hr}$, and tomato and its combination have respiration rates of $5.24 \mathrm{ml} \mathrm{CO}_{2} / \mathrm{hr}$ and $4.13 \mathrm{ml} \mathrm{CO} / \mathrm{hr}$, respectively. The potato has the lowest respiration rate, and the transportation method of potato, tomato and their combination is shown in Table II.

However, the respiration rate changes in the closed transportation according to the headspace; if the headspace decreases, then the respiration rate also decreases. In comparison, the potato has a less respiration rate than tomato. However, both have reduced respiration in the closed transportation. Complete production of $\mathrm{CO}_{2}$ emission is shown in Table II, which is estimated by applying the respiration rates to the overall production of agriculture production during past three years of 2014, because this work is conducted during the year of 2014. Thus, the overall $\mathrm{CO}_{2}$ emission of Indian traditional ASCM will increase.

\subsection{Calculation of loss and $\mathrm{CO}_{2}$ emission}

The $\mathrm{CO}_{2}$ emission is not only produced by the transported agricultural produces but also emitted during PHL. Therefore, supply and loss are major sources of $\mathrm{CO}_{2}$ emissions, which will increase the environmental impacts of Indian traditional ASCM. Table III comprises the loss of all three combinations such as potato, tomato and mixture of both, with total PHL in terms of $\mathrm{kg}$ for an assumed percentage of PHL for each stage, as well as supply structures and exact production of each year. If the traditional ASCM adopts type 1 supply structure, it will have 50 percent of PHL, leaving highest quantity of loss; otherwise if it adopts a most optimized supply structure type 3 with 10 percent of PHL, it will be the lowest loss. The comparison of type 1 and type 3 reveals that the total loss reduced to 15 percent in all percentage of PHL.

The PHL percentages of each stage and supply structure are interlinked with each other. The optimized supply structure reduces the loss and $\mathrm{CO}_{2}$ emission, but the transportation method reduces $\mathrm{CO}_{2}$ emission only. Tables IV and $\mathrm{V}$ comprise the $\mathrm{CO}_{2}$ emission of loss produces during closed and open transportation, respectively. Table IV shows the significance of closed transportation by comparing $\mathrm{CO}_{2}$ emission produced by selected produce respiration along with an assumed percentage of PHL and optimized supply structures.

Table IV clarifies that the PHL of tomato in supply structure type 3 has lowest $\mathrm{CO}_{2}$ emission, which is $5,10,15,18$, and 22 percent with respect to each percentage of PHL. The supply structure type 3 of potato has $\mathrm{CO}_{2}$ emission of 7, 14, 20 25, and 29 percent with respect to each percentage of PHL, which is slightly higher than tomato. The supply structure type 3 of mixed produces has $\mathrm{CO}_{2}$ emission of $6,12,17,22$, and 25 percent with respect to each percentage of PHL. Therefore, the tomato has lowest $\mathrm{CO}_{2}$ than both, but the potato $\mathrm{CO}_{2}$ emission can be reduced by mixing both. The open transportation $\mathrm{CO}_{2}$ emission is estimated and shown in Table $\mathrm{V}$ to compare with closed transportation.

Table $\mathrm{V}$ clarifies the differentiation of $\mathrm{CO}_{2}$ emission of open transportations of selected produces compared with the PHL percentage and optimized supply structures, because this open transportation is more traditional than the existing transportation method. Table $\mathrm{V}$ clarifies that the $\mathrm{CO}_{2}$ emission of open transportation is much higher. The potato has 90 percent of $\mathrm{CO}_{2}$ emission in supply structure type 1with highest loss percentage. This table is used here to estimate the current $\mathrm{CO}_{2}$ emission of selected produces for five different loss and three different supply structures. In Table $\mathrm{V}$, it is estimated to compare the closed transportation with traditional open transportation. The difference between closed and traditional open transportation is shown in Table VI. 
IMDS

117,9

\section{4}

Table III.

Total loss of each supply stage
离

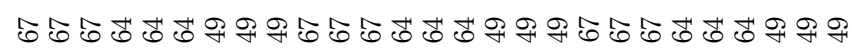

द

৪৪৪

$\stackrel{\circ}{\circ}$

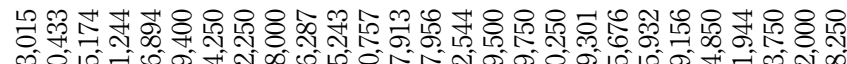

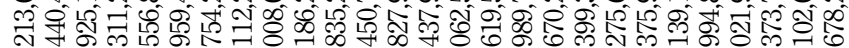

की

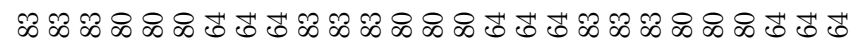

@े

m น

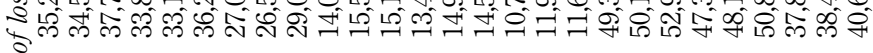

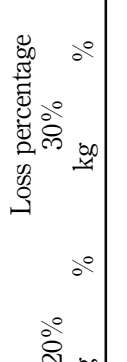

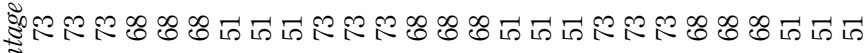

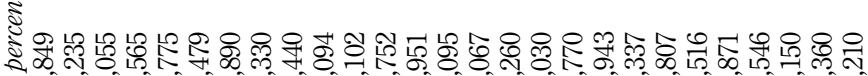

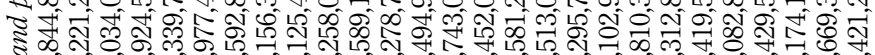

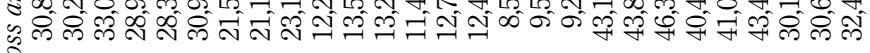

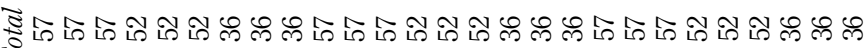
$R$

จे

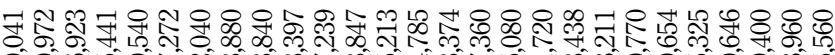

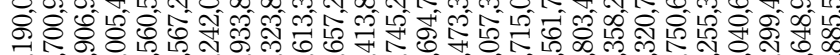
सิ

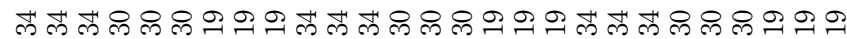

$\stackrel{\circ}{\circ}$

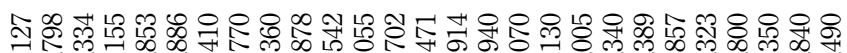
乐 of की

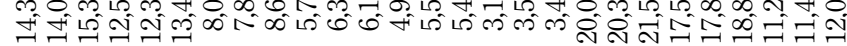

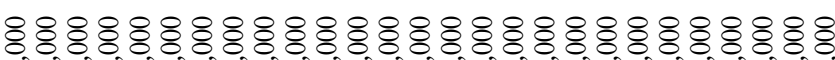

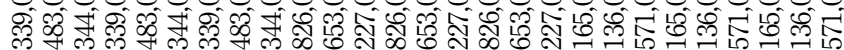

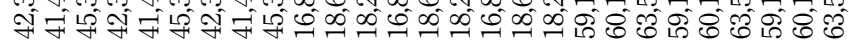

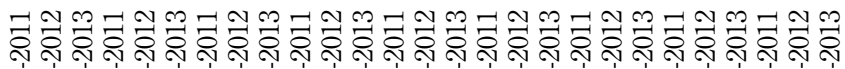

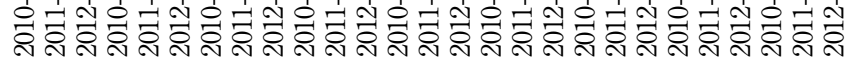

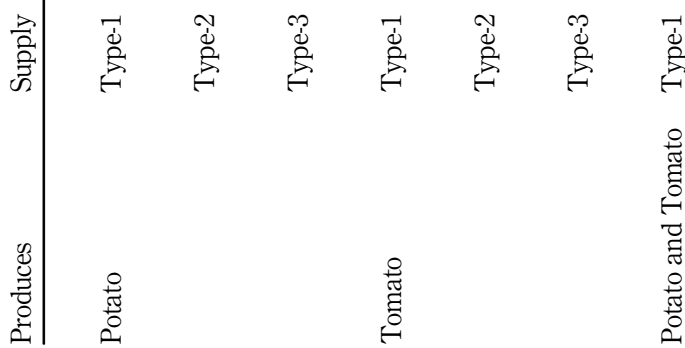


Table IV. 
IMDS

117,9

1836

Table V.

$\mathrm{CO}_{2}$ emission by open transportation

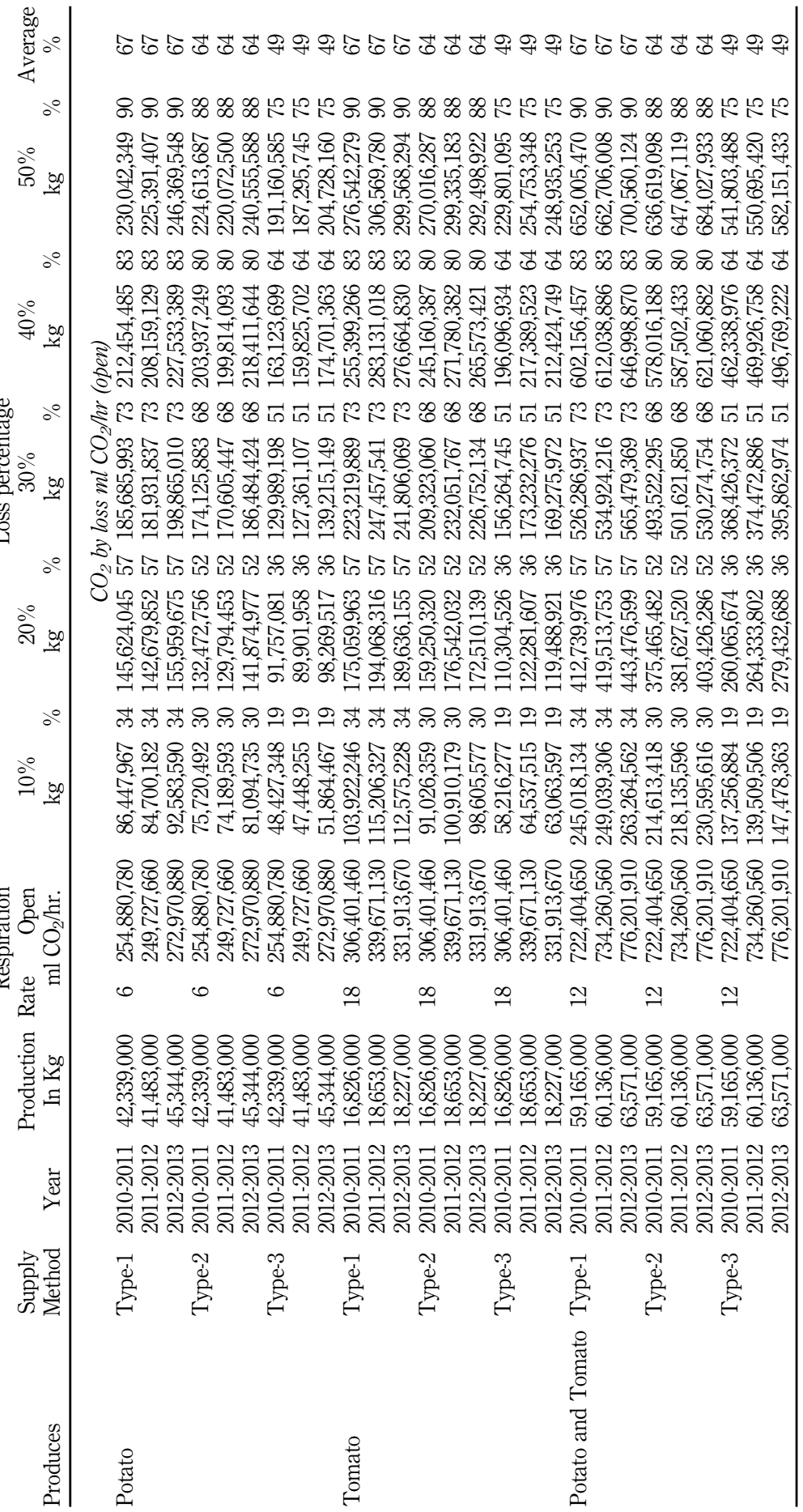


IMDS

117,9

1838

Table VI depicts the differentiation of $\mathrm{CO}_{2}$ emission of open and closed transportation compared with PHL percentage and optimized supply structure. The open transportation has high $\mathrm{CO}_{2}$ emission than the closed transportation. It clearly clarifies that in supply structure type 3 , the potato has lowest differentiation of $12,22,31,39$, and 46 percent with respect to all $\mathrm{PHL}$ percentage, because the potato has moderate respiration in closed transportation. By comparing Tables IV-VI, the lowest and highest $\mathrm{CO}_{2}$ emissions of individual produces are identified. However, if the produces are mixed together, then the produces emit moderately. If tomato and potato are combined together and transported, then overall emission is reduced.

\section{Conclusion}

In this paper, Indian traditional ASCM was modeled as a planning model by considering intermediaries to reduce the $\mathrm{PHL}$ and $\mathrm{CO}_{2}$ emission, through optimizing the supply structures and modified transportation method, respectively. This model is optimized through GA with constraints. Three alternative supply structures were considered, undergoing an optimization amongst three. One of the methods was found to have a reduced PHL. The overall losses are reduced through the optimized supply structures like type 1 , type 2 and type 3 . The PHLs are compared with each other to identify the optimized supply structure. The supply structure type-1 approximately replicates the existing SC, because type-1 supply structure transports produces from farmer to customer through intermediaries.

Succeeding, supply structure type-1 has average PHL of 67 percent for potato, tomato and their combination. Consequently, supply structure type-3 has lowest average PHL of 49 percent. Likewise, the supply structure type- 1 and type- 3 emits 67 and 49 percent of $\mathrm{CO}_{2}$, respectively, during open transportation. Therefore, type-3 supply structure is found as well-optimized supply structure for each produce and their combinations. Even though supply structures are optimized to reduce loss, $\mathrm{CO}_{2}$ emission is high due to open transportation. Therefore, the closed transportation is identified as alternative transportation method for potato, tomato and their combination, because the $\mathrm{CO}_{2}$ emission is highly reduced as compared to open transportation, and in this closed transportation, tomato has lowest emission of 14 percent.

The combination of potato and tomato has $\mathrm{CO}_{2}$ emission of 16 percent, which is higher than tomato but lower than potato. However, this mixed closed transportation reduces $\mathrm{CO}_{2}$ emission of potato. Therefore, this research paper identified that the mixed closed transportation is the best transportation method for the short-duration domestic purpose. These supply structures and the mixed closed transportation method can only be implemented when shortest distance markets are grouped together. This grouping reduces the traveling distance and time.

\section{Future work}

Further this model can be extended to other produces, which is most commonly available produces to estimate the $\mathrm{CO}_{2}$ emission and losses. Because each produces has its own respiration rate, so measuring the respiration rate of other produces to estimate the emission becomes crucial.

\section{References}

Ahumada, O. and Villalobos, J.R. (2009), "Application of planning models in the agri-food supply chain: a review”, European Journal of Operational Research, Vol. 196 No. 1, pp. 1-20.

Alexandratos, N. and Bruinsma, J. (2012), "World agriculture towards 2030/2050: the 2012 revision", ESA Working Paper No. 12-03, FAO, Rome. 
Amrutlal, P.A. (2010), "An in-depth comparative study of supply chain management practices at selected agriculture produce marketing committees of north Gujarat", $\mathrm{PhD}$ thesis, Ganpat University, Ganpat Vidhyanagar.

Ashby, H. (2008), Protecting Perishable Foods During Transport by Truck, Agricultural Marketing Service, Washington, DC.

Bahinipati, B.K. (2014), "The procurement perspectives of fruits and vegetables supply chain planning", International Journal of Supply Chain Management, Vol. 3 No. 2, pp. 111-131.

Bala, K. (2014), "Supply chain management: some issues and challenges - a review", International Journal of Current Engineering and Technology, Vol. 4 No. 2, pp. 946-953.

Beamon, B.M. (1999), "Designing the green supply chain”, Logistics Information Management, Vol. 12 No. 4, pp. 332-342.

Bhateja, A.K., Babbar, R., Singh, S. and Sachdeva, A. (2011), "Study of green supply chain management in the Indian manufacturing industries: a literature review cum an analytical approach for the measurement of performance", International Journal of Computational Engineering and Management, Vol. 13 No. 3, pp. 84-98.

Bhushan, N. (2013), Post-Harvest Profile of Mango, Department of Agriculture \& Cooperation, Directorate of Marketing \& Inspection, Nagpur.

Blok, K., Jager, D.D. and Hendriks, C. (2001), Economic Evaluation of Sectoral Emission Reduction Objectives for Climate Change, European Commission, Utrecht.

Dalei, N.N. and Dutta, P.K. (2015), "Sharecropping system and its supply chain management: a case study from coastal belt of Odisha”, International Journal of Applied Research, Vol. 6 No. 1, pp. 50-56.

Dimopoulos, C. and Zalzala, A.M.S. (2000), "Recent developments in evolutionary computation for manufacturing optimization: problems, solutions, and comparisons", IEEE Transactions on Evolutionary Computation, Vol. 4 No. 2, pp. 93-113.

Etemadnia, H., Goetz, S.J., Canning, P. and Tavallali, M.S. (2015), "Optimal wholesale facilities location within the fruit and vegetables supply chain with bimodal transportation options: an LP-MIP heuristic approach", European Journal of Operational Research, Vol. 244 No. 2, pp. 648-661.

Fahimnia, B., Davarzani, H. and Eshragh, A. (In press), "Planning of complex supply chains: a performance comparison of three meta-heuristic algorithms", Computers \& Operations Research, doi: http://dx.doi.org/10.1016/j.cor.2015.10.008i.

FAO (2005), Towards an Indian Common Market, Ministry of Agriculture, Government of India, New Delhi.

Fonseca, S.C., Oliveira, F.A.R. and Brecht, J.K. (2002), "Modelling respiration rate of fresh fruits and vegetables for modified atmosphere packages: a review", Journal of Food Engineering, Vol. 52 No. 2, pp. 99-119.

Gangwar, L.S., Singh, D. and Singh, D.B. (2007), "Estimation of post-harvest losses in kinnow mandarin in punjab using a modified formula", Agricultural Economics Research Review, Vol. 20 No. 2, pp. 315-331.

Gigler, J.K., Hendrix, E.M.T., Heesen, R.A., van den Hazelkamp, V.G.W. and Meerdink, G. (2002), "On optimisation of agri chains by dynamic programming", European Journal of Operational Research, Vol. 139 No. 3, pp. 613-625.

Gustavsson, J., Cederberg, C., Sonesson, U., Otterdijk, R.v. and Meybeck, A. (2011), Global Food Losses and Food Waste, Food and Agriculture Organization of the United Nations, Rome.

Hodges, R.J., Buzby, J.C. and Bennett, B. (2011), "Postharvest losses and waste in developed and less developed countries: opportunities to improve resource use", The Journal of Agricultural Science, Vol. 149 No. S1, pp. 37-45.

Jang, W. and Klein, C.M. (2011), "Supply chain models for small agricultural enterprises", Annals of Operations Research, Vol. 190 No. 1, pp. 359-374. 
IMDS 117,9

Jansen, H.G.P. (1996), "Agricultural marketing in the Atlantic zone of Costa Rica: a production, consumption and trade study of agricultural commodities produced by small and medium scale farmers", Centro agronómico tropical de investigación y enseñanza, Turrialba.

Joshi, R., Banwet, D.K. and Shankar, R. (2009), "Indian cold chain: modeling the inhibitors", British Food Journal, Vol. 111 No. 11, pp. 1260-1283.

Kader, A.A. and Rolle, R.S. (2004), The Role of Post-Harvest Management in Assuring the Quality and Safety of Horticultural produce, Rome, FAO.

Kannan, G., Sasikumar, P. and Devika, K. (2010), "A genetic algorithm approach for solving a closed loop supply chain model: a case of battery recycling”, Applied Mathematical Modelling, Vol. 34 No. 3, pp. 655-670.

Klerkx, L. and Leeuwis, C. (2008), "Matching demand and supply in the agricultural knowledge infrastructure: experiences with innovation intermediaries", Food Policy, Vol. 33 No. 3, pp. 260-276.

Kumar, R. and Chandrakar, R. (2012), "Overview of Green supply chain management: operation and environmental impact at different stages of the supply chain", International Journal of Engineering and Advanced Technology, Vol. 1 No. 3, pp. 1-6.

Lummus, R.R., Krumwiede, D.W. and Vokurka, R.J. (2001), "The relationship of logistics to supply chain management: developing a common industry definition", Industrial Management \& Data Systems, Vol. 101 No. 8, pp. 426-432.

Mula, J., Peidro, D., Díaz-Madroñero, M. and Vicens, E. (2010), "Mathematical programming models for supply chain production and transport planning", European Journal of Operational Research, Vol. 204 No. 3, pp. 377-390.

Murthy, D.S., Gajanana, T.M., Sudha, M. and Dakshinamoorthy, V. (2007), "Marketing losses and their impact on marketing margins", Agricultural Economics Research Review, Vol. 20 No. 1, pp. $47-60$.

Naso, D., Surico, M., Turchiano, B. and Kaymak, U. (2007), "Genetic algorithms for supply-chain scheduling: a case study in the distribution of ready-mixed concrete", European Journal of Operational Research, Vol. 177 No. 3, pp. 2069-2099.

Negi, S. and Anand, N. (2015a), "Cold chain: a weak link in the fruits and vegetables supply chain in India”, IUP Journal of Supply Chain Management, Vol. 12 No. 1, pp. 48-62.

Negi, S. and Anand, N. (2015b), "Issues and challenges in the supply chain of fruits \& vegetables sector in India: a review", International Journal of Managing Value and Supply Chains, Vol. 6 No. 2, pp. 48-62.

Neven, D., Odera, M.M., Reardon, T. and Wang, H. (2009), "Kenyan supermarkets, emerging middle-class horticultural farmers, and employment impacts on the rural poor", World Development, Vol. 37 No. 11, pp. 1802-1811.

Parfitt, J., Barthel, M. and Macnaughton, S. (2010), "Food waste within food supply chains: quantification and potential for change to 2050", Philosophical Transactions of the Royal Society B: Biological Sciences, Vol. 365 No. 1554, pp. 3065-3081.

Rajkumar, P. and Jacob, F. (2010), "Business models of vegetable retailers in India”, Great Lakes Herald, Vol. 4 No. 1, pp. 31-43.

Ratinger, T. (2013), "Food loses in the selected food supply chains", 140th EAAE Seminar, "Theories and Empirical Applications on Policy and Governance of Agri-food Value Chains", European Association of Agricultural Economists, Perugia.

Schils, R.L.M., Verhagen, A., Aarts, H.F.M. and Šebek, L.B.J. (2005), "A farm level approach to define successful mitigation strategies for GHG emissions from ruminant livestock systems", Nutrient Cycling in Agroecosystems, Vol. 71 No. 2, pp. 163-175.

Sharma, G. and Singh, S.P. (2011), "Economic analysis of post-harvest losses in marketing of vegetables in Uttarakhand", Agricultural Economics Review Research, Vol. 24 No. 2, pp. 309-315. 
Shukla, M. and Jharkharia, S. (2013), "Agri-fresh produce supply chain management: a state-of-the-art literature review”, International Journal of Operations \& Production Management, Vol. 33 No. 2, pp. 114-158.

Snowden, A.L. (2010), Post-Harvest Diseases and Disorders of Fruits and Vegetables: Volume 1: General Introduction and Fruits, Manson Publishing, London.

Indian

traditional

agriculture

supply chain

Syahruddin, N. and Kalchschmidt, M. (2011), "POM 2011 - 22nd annual conference of the production and operations management society", Production and Operations Management Society, May 9-12, 2014, Nevada, NV.

UNEP (2012), “The emissions gap report 2012”, UNEP, Nairobi.

Vigneault, C., Thompson, J., Wu, S., Hui, K.P.C. and LeBlanc, D.I. (2009), "Transportation of fresh horticultural produce", Postharvest Technologies for Horticultural Crops, Vol. 2, pp. 1-24.

Vorst, J.G.A.J.V.D., Tromp, S. and Zee, D.J.V.D. (2010), "Simulation modelling for food supply chain redesign; integrated decision making on product quality, sustainability and logistics", International Journal of Production Research, Vol. 47 No. 23, pp. 6611-6631.

Xie, J. and Dong, J. (2002), "Heuristic genetic algorithms for general capacitated lot-sizing problems", Computers \& Mathematics with Applications, Vol. 44 Nos 1-2, pp. 263-276.

Yahia, E.M. (2009), Modified and Controlled Atmospheres for the Storage, Transportation, and Packaging of Horticultural Commodities (edited by Yahia, E.M.), CRC Press, Boca Raton, Florida.

\section{Corresponding author}

Manivannan Chandrasekaran can be contacted at: manivannanchandru@gmail.com

For instructions on how to order reprints of this article, please visit our website: 